\title{
Program Evaluation of a High School Summer Bridge Program in Chemistry and Engineering (Evaluation)
}

\section{Dr. Amanda Simson, The Cooper Union}

Amanda Simson was appointed Assistant Professor of Chemical Engineering at The Cooper Union in August 2017. Her research focuses on using heterogeneous catalysis in applications like emissions control and alternative energy technologies. Amanda received her Ph.D. from Columbia University's Department of Earth and Environmental Engineering. After her PhD she worked on developing hydrogen production technologies for Watt Fuel Cell in Port Washington, NY. Dr. Simson is dedicated to improving educational opportunities for students in STEM. Prior to her PhD studies she taught middle school for three years, two as part of the Teach for America program. She has developed several programs for students including a series of math competitions for NYC middle school students and a chemistry card game called Valence.

\section{Dr. Laura C. Broughton, City University of New York, Bronx Community}

Laura Broughton is an Associate Professor of biological sciences at Bronx Community College of the City University of New York. She earned her Ph.D. in Zoology and Ecology, Evolutionary Biology and Behavior. Her interests include effective teaching in STEM fields, quantitative literacy, increasing diversity in STEM fields, microbial ecology, and environmental justice. She has run faculty development programs for new faculty members, online course development, and incorporating quantitative literacy into courses.

\section{Dr. Elizabeth J. Biddinger, City College of the City University of New York}

Elizabeth J. Biddinger, PhD is an Assistant Professor in the Department of Chemical Engineering at The City College of New York. She received her B.S. from Ohio University (2005) and PhD from The Ohio State University (2010), both in chemical engineering. Prior to joining The City College of New York, Biddinger was a post-doctoral fellow at the Georgia Institute of Technology. Biddinger's educational interests lie in chemical reaction engineering, incorporating laboratory experiences into traditional coursework, and bringing awareness of electrochemical engineering to chemical engineers. Biddinger's research involves applications of green chemistry and energy utilizing electrocatalysis, batteries, and novel solvents. 


\title{
Program evaluation of a high school summer bridge program in chemistry and engineering
}

\begin{abstract}
In this paper we evaluate a summer college preparatory program for New York City high school students housed at Bronx Community College. The program was titled "Introduction to Energy Technology" and it focused on teaching chemistry and engineering skills in the context of traditional and alternative energy applications. The program has run for two summers, in 2017 and 2018, and has had 35 students participate. During the full day, six-week program, students attended chemistry and engineering lectures, Excel sessions, math tutoring, and a daily afternoon laboratory. The calendar also included a college panel and an energy plant tour. In addition to the learning objectives of the course, a set of 30 specific skills were targeted and students selfevaluated their confidence in these skills at the beginning and end of the program. Students were also surveyed on their interest in STEM, their confidence in different subjects, and their career goals. Results of these surveys found that students' confidence in chemistry, engineering and computer skills increased as a result of the course. The most significant increases were observed in engineering skills because initial confidence levels in this area were low. A majority of students reported increased interest in STEM fields and 100\% of students (during the 2018 cohort) reported that increasing their confidence in science, math and engineering contributed to this intensified interest. This program evaluation reviews the program's objectives, format, teaching tools, student feedback and plans for future programming and assessment.
\end{abstract}

Introduction

The need for STEM-educated workers is long-standing and well-established [1, 2]. The US government has responded by encouraging the development of a STEM pipeline to build capacity from primary school through graduate school [3, 4]. Minorities and women, in particular, are underrepresented in STEM fields [1,2]. The underrepresentation of minorities and women in STEM fields is affected by students' choice of major, which is, in turn, affected by factors like the students' mathematics or science grades in high school and their parents' level of education [5,6] and students' confidence in their academic and mathematical skills [7].

Institutionalized economic, academic, and cultural barriers also contribute to underrepresentation $[8,9,10,11]$. Students' success in STEM has been shown to be linked to their self-confidence in the topics $[12,13,14]$. Further, beginning engineering students have been found to lack an understanding of what an engineering career entails $[14,15]$. Thus, to increase the number and diversity of students choosing STEM careers, it is important to develop pipelines for students to introduce them to STEM careers before college and to increase their confidence in STEM-related skills.

Programs to address STEM skills, self-confidence, or understanding of STEM careers have targeted various time frames throughout the STEM pipeline, including high school [16, 17], summer bridge programs for high school to college [14, 18, 19], co-curricular support in college [20,21], and 2-year to 4-year college bridge programs [13]. The majority of summer bridge programs target students already accepted to a college for an intensive summer program that aims to improve student skill levels and confidence [14], often for credit [14, 22]; these programs 
have been shown to be effective in improving students' mathematics skills [14, 19, 22] and their understanding of the field of engineering [14].

The summer bridge program evaluated in this paper was offered as part of an existing collaborative program between the City University of New York and the New York City public high school system called College Now [23]. College Now is a free, non-residential, college transition program that serves public high school juniors and seniors from across the five boroughs of New York City; students take pre-college and credit-bearing college courses but, unlike most existing summer bridge programs, are not required to be enrolled in a CUNY school [23]. Over $80 \%$ of the students in the CUNY-wide College Now program self-identify as minority students and approximately $60 \%$ are female [24].

\section{Background}

The 2-credit, college-level, College Now course, EST 11: Introduction to Energy Technology, ran Monday-Thursday, 9:00am-3:00pm for approximately 6 weeks during the summer of 2017 and the summer of 2018. The course had one primary instructor (a visiting professor from a local private college) and teaching assistants that were engineering undergraduate students. The course had an enrollment of 16 students (Summer 2017) and 19 students (Summer 2018) who attended local NYC public high schools.

The students who participated in the College Now EST 11 course had similar demographics to the entire Bronx Community College (BCC) College Now portion of the CUNY-wide program. At BCC, the College Now student population was composed of 54.7\% Hispanic, 34.7\% Black, 5.2\% Asian or Pacific Islander, 2.1\% White, 0.5\% American Indian or Alaskan Native and 2.8\% unknown. The program at BCC was $62.5 \%$ females and $37.5 \%$ males.

Of students surveyed in the 2018 cohort of EST 11, a majority were high school seniors (71\%) and had already taken Chemistry $(86 \%)$, but not yet taken Physics $(21 \%)$. The majority of students said they intended to apply to four-year programs after high school, and all students surveyed intended to ultimately get a four-year degree. A majority of students $(62 \%)$ had not taken an Advance Placement course.

The course was designed as part of larger project that aims to increase the percentage of minorities and women that work in sustainable chemical and bioenergy technologies. The project also included the design of two college-level classes. This summer bridge course, EST 11, piloted portions of one of these 4-credit courses designed for students at Bronx Community College. EST 11 was funded through both the College Now program and NSF ATE Project \#1601636 - Chemical and BioEnergy Technology for Sustainability (CBETS).

\section{Curricular Design}

The program focused on introducing high school students to the fields of Chemistry, Chemical Engineering and Energy Technology while improving their computer skills, math skills, and preparing them for college life. The goal was to increase student engagement with STEM fields, but also to give them the skills to succeed in an engineering program in college. The course was 
organized into four primary sections: Introduction to Physical Properties, Introduction to Chemistry, Introduction to Chemical Engineering, and Applications to Energy Technologies. The class consisted of a morning 75-minute lecture (with problem sets and activities) on these topics and a 90-120-minute afternoon laboratory designed to use skills learned in the morning section. Additionally, students spent 45 minutes learning Excel skills and 45 minutes in a math tutoring session. The course was designed so that skills acquired in the math and computer sections were also utilized shortly thereafter in both the primary Chemistry/Engineering lecture and in the laboratory. The topics list for each portion of the program is shown in Table I.

The first portion of the course focused on skill building within chemistry, math and engineering whereas the second portion of the course focused on using these skills for applications to energy and electricity production. In the last two weeks of the course, topics included: sustainability, the carbon cycle, electric power plants and steam, hydrocarbon fuels, and alternative energy technologies. The students attended a field trip to the ConEdison steam plant in NYC and had two laboratories focused on energy technology: calculating the energy content of biomass (nuts) and creating biodiesel from waste bio-oil. Students also completed two projects: one on methods to produce electricity and one on a commodity chemical. The laboratory units for the physical property studies were modified from Vernier examples. The later laboratory experiments utilized 10L tank reactors and experiments modified from those developed at The City College of New York [25] to give students a sense of scale in chemical engineering.

In addition to the topics in math, chemistry, and engineering, a set of learning objectives and experiences were incorporated to prepare students to succeed in college. As shown in Table 1, sections of the course were devoted to teaching study and test taking skills, presentation skills, and note-taking. Students also participated in a college panel and a campus tour. Additionally, students were exposed to common college practices like office hours, course syllabi, course readings, and class discussions. In the 2018 course, specific time was set aside to allow students to work on their own (with freedom to work anywhere on campus). These portions of time were specifically designed to give students choices in how to manage their time.

The course, which drew juniors and seniors from various local high schools, did not have specific prerequisites. Thus, a fundamental challenge of the course was to incorporate differentiation into the curriculum delivery to meet the needs of a variety of skill levels. To accommodate all students, each section of the course included peer-peer tutoring, office hours during lunch, and optional assignments for students that were more advanced or for students that required additional resources.

Future work in curriculum design will focus on scientific communication. Although short laboratory reports and two presentations were required and graded, there was not explicit instruction or feedback given on writing. Instead, a majority of the focus of technical communication instruction was on developing clear and well formatted plots and tables. Integrating an additional writing assignment explicitly designed with a revision process could give students an idea of what college level scientific writing looks like. 
Table 1: Course Topics organized by section and week

\begin{tabular}{|c|c|c|c|c|}
\hline 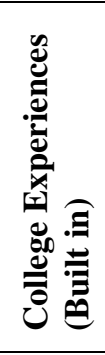 & 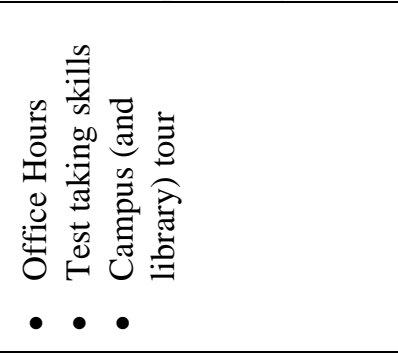 & 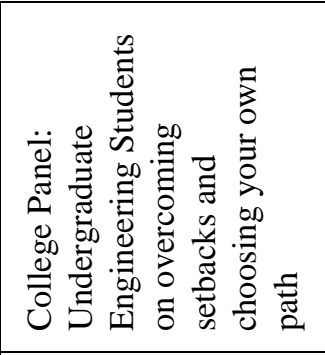 & 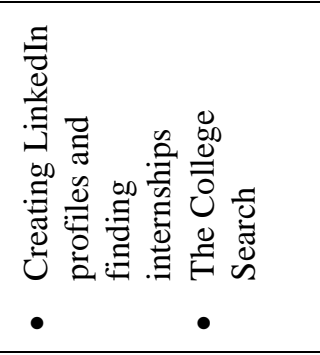 & 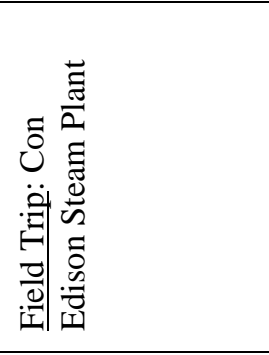 \\
\hline 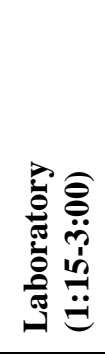 & 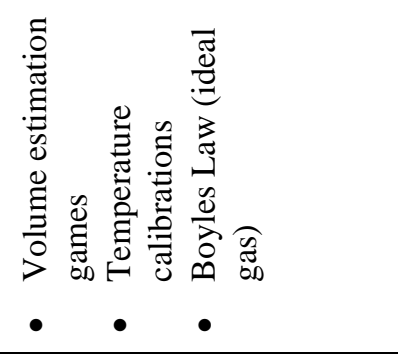 & 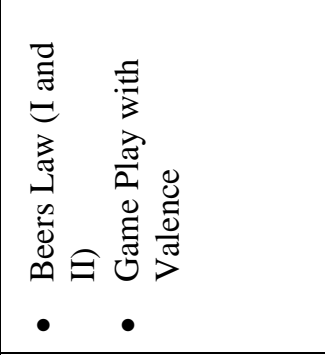 & 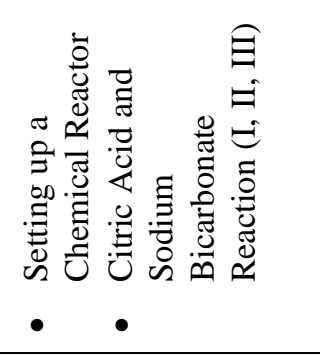 & 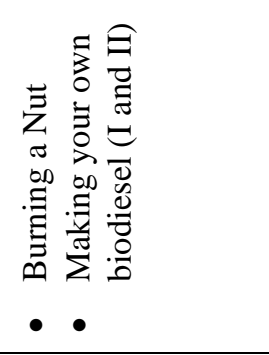 \\
\hline 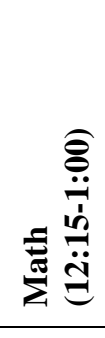 & 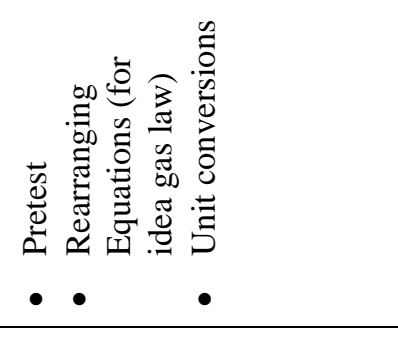 & 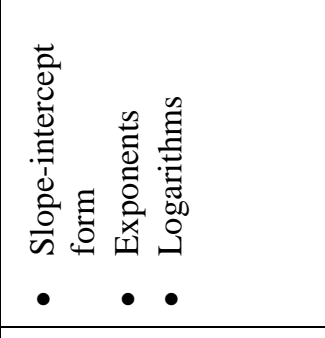 & 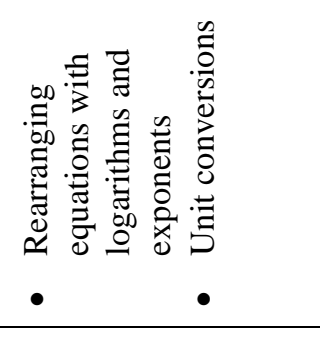 & 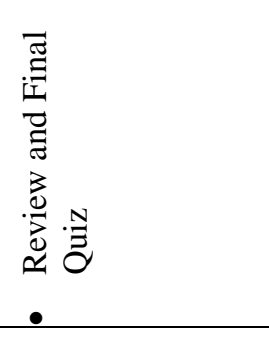 \\
\hline 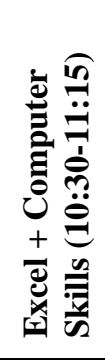 & 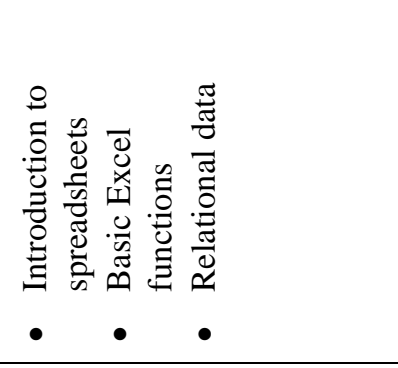 & 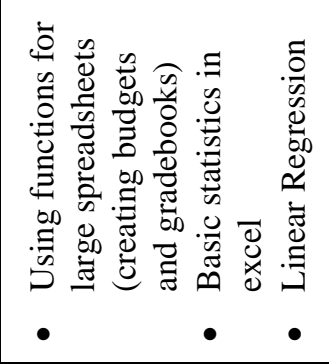 & 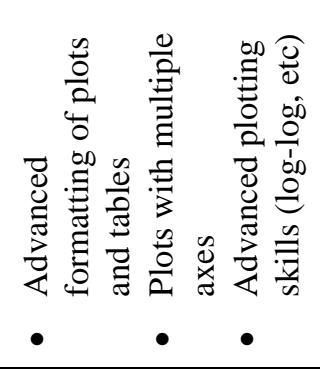 & 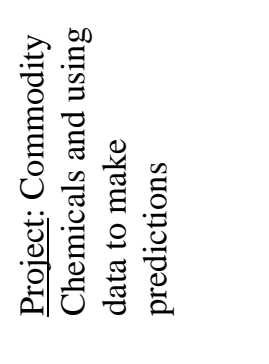 \\
\hline 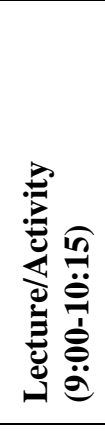 & 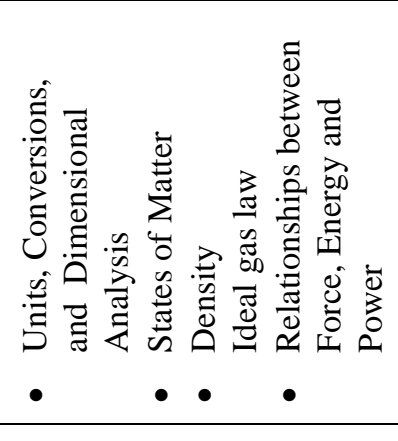 & 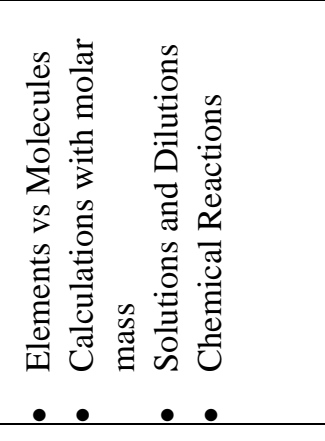 & 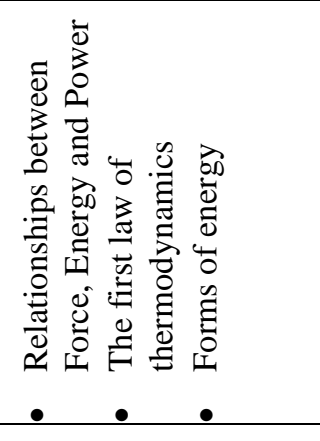 & 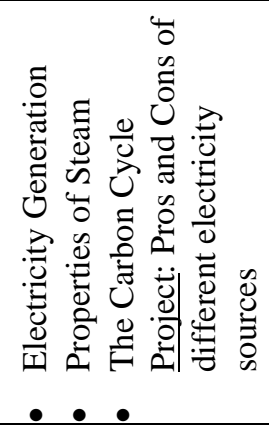 \\
\hline 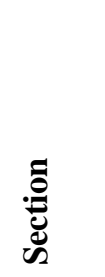 & 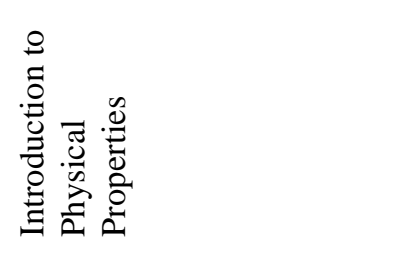 & 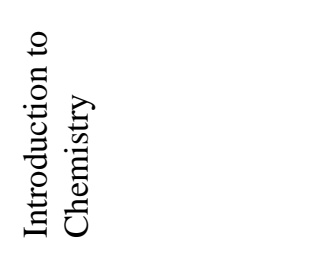 & 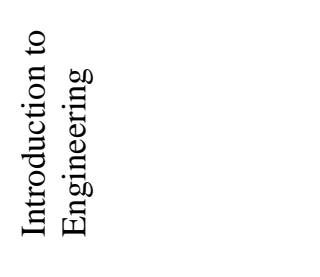 & 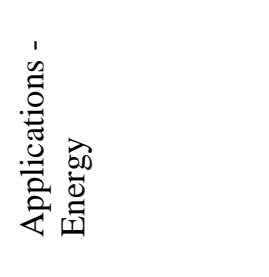 \\
\hline
\end{tabular}




\section{Program Evaluation}

We evaluated the course using two tools: a skills assessment performed at the beginning and end of the course, and a student engagement survey performed at the end of the course. Both tools were used for both the 2017 and 2018 cohorts. In some cases, slight modifications were made between the 2017 and 2018 tools as noted in the assessment below. The student engagement survey also asked students to reflect on what they learned in the course, and asked them to reflect on how the course could be improved.

\section{Skills assessment}

Student performance was evaluated through a pre and post exam in mathematics, several quizzes and a final exam in the course, and through assignments and presentations. In addition, students self-evaluated themselves at the beginning and end of the course on a list of skills that were covered. Students rated their confidence in each skill on a 4-point scale at the beginning and end of the course. The average score for skills in each category is shown in Figure 1 for both the 2017 and 2018 cohort of students. At the beginning of the course, students felt the most confident in chemistry skills and the least confident in their Excel skills and in their understanding of applications of Chemistry and Engineering. A majority of students in both the 2017 and 2018 cohorts had never used Excel. However, at the beginning of the course, no more than $25 \%$ of students rated any given skill a 4 (fully competent or advanced user), indicating that for most students the entirety of material presented in the course was new material or material that students had little confidence in. However, standard deviations between 0.7 and 1.7 (on a 4point scale) were measured for each category indicating strong variation in initial skill levels. Thus, the pre-assessment indicated that the material was appropriate, but differentiation was required to manage the variable foundational skills within the class.

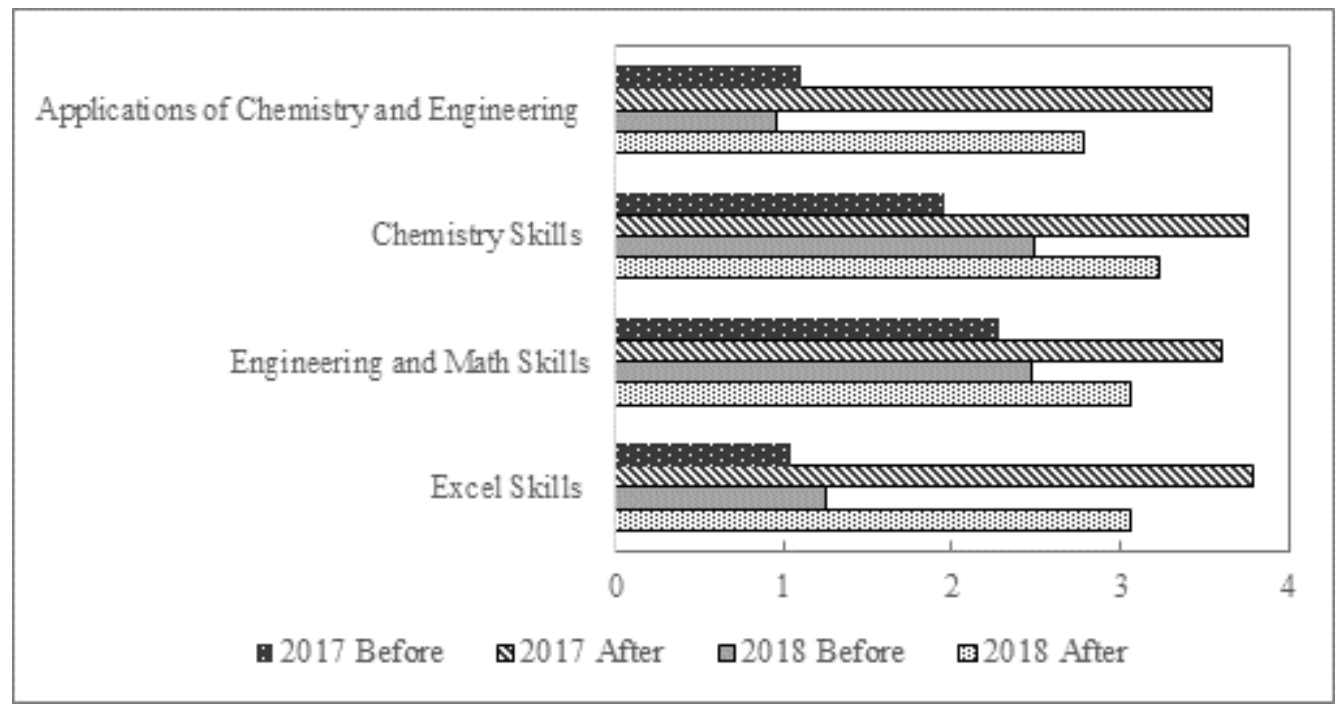

Figure 1: Self-assessed confidence levels in course objectives on 4-point scale before and after taking the course. Only cumulative scores are shown for 2017 and 2018 cohort of students.

After the course, students reported gains in confidence in each individual skill (breakdown within category of skills is not shown), and standard deviations for each category were smaller 
(ranging from 0.3 to 1.1) indicating variation was reduced for end-of semester skill levels. Student confidence increased most significantly in Excel skills for both the 2017 and 2018 cohorts, likely because these were skills students had not had exposure to and were able to master in the period of the course. Excel skills were taught in the computer sessions, and then reinforced in the laboratory. Thus, students were able to see the usefulness of the skills and apply them in new ways, which may have reinforced their confidence in them. Specific topics that students reported the lowest confidence levels for at the end of the course are shown in Table 2. These are shown to demonstrate areas of the curriculum could be improved. Most of these skills were ones that students had little initial experience (such as knowing the components of a traditional power plant) and thus had significant learning gains. However, certain skills such "Calculations involving concentrations of solutions" and several related to data analysis such as "Identifying independent and dependent variables" may be harder for students to learn and require additional time for future iterations of the course.

Table 2: Topics that students reported the lowest confidence in at the end of the course. Learning gains shown as average increase on a 4-point scale in parenthesis.

\begin{tabular}{|l|l|l|}
\hline Topic Area: & $\begin{array}{l}\text { 2017 Cohort - topics with lowest } \\
\text { learning gains }\end{array}$ & $\begin{array}{l}\text { 2018 Cohort - topics with lowest } \\
\text { learning gains }\end{array}$ \\
\hline $\begin{array}{l}\text { Applications of Chemistry and } \\
\text { Engineering }\end{array}$ & $\begin{array}{l}\text { Describe the main component of a } \\
\text { traditional steam power plant }(2.57)\end{array}$ & $\begin{array}{l}\text { Describe the main component of a } \\
\text { traditional steam power plant (1.92) }\end{array}$ \\
\hline Chemistry & $\begin{array}{l}\text { Balancing a Chemical Reaction } \\
(1.86)\end{array}$ & $\begin{array}{l}\text { Calculations involving } \\
\text { concentrations of solutions }(0.57)\end{array}$ \\
\hline Engineering and Math & $\begin{array}{l}\text { Identifying independent and } \\
\text { dependent variables }(0.79)\end{array}$ & $\begin{array}{l}\text { Analyzing sets of data and } \\
\text { developing lines of best fit }(0.52)\end{array}$ \\
\hline Excel & Using Absolute Addresses (2.64) & $\begin{array}{l}\text { Using slope and y-intercept to } \\
\text { predict outcomes }(1.2)\end{array}$ \\
\hline
\end{tabular}

\section{College Experience and Soft Skills}

Students were surveyed on their interest in acquiring different non-technical skills before and after the course. This aspect of the survey was performed only for the 2018 cohort. As shown in Figure 2, results before and after the course differed significantly. Students were more interested in getting instruction in time management after taking the college level course. Additionally, students were more interested in gaining instruction in "How to study" and "Test preparation and test taking skills" and "career planning" after the course. These responses were surprising because explicit instruction was given in time management, test taking skills, and career planning (including decisions on choosing your major, finding internships, etc.). We hypothesize that this result may be because students recognized the value of these topics after the course, and therefore, despite having more understanding of these areas, placed more of a priority on gaining more instruction in them. 


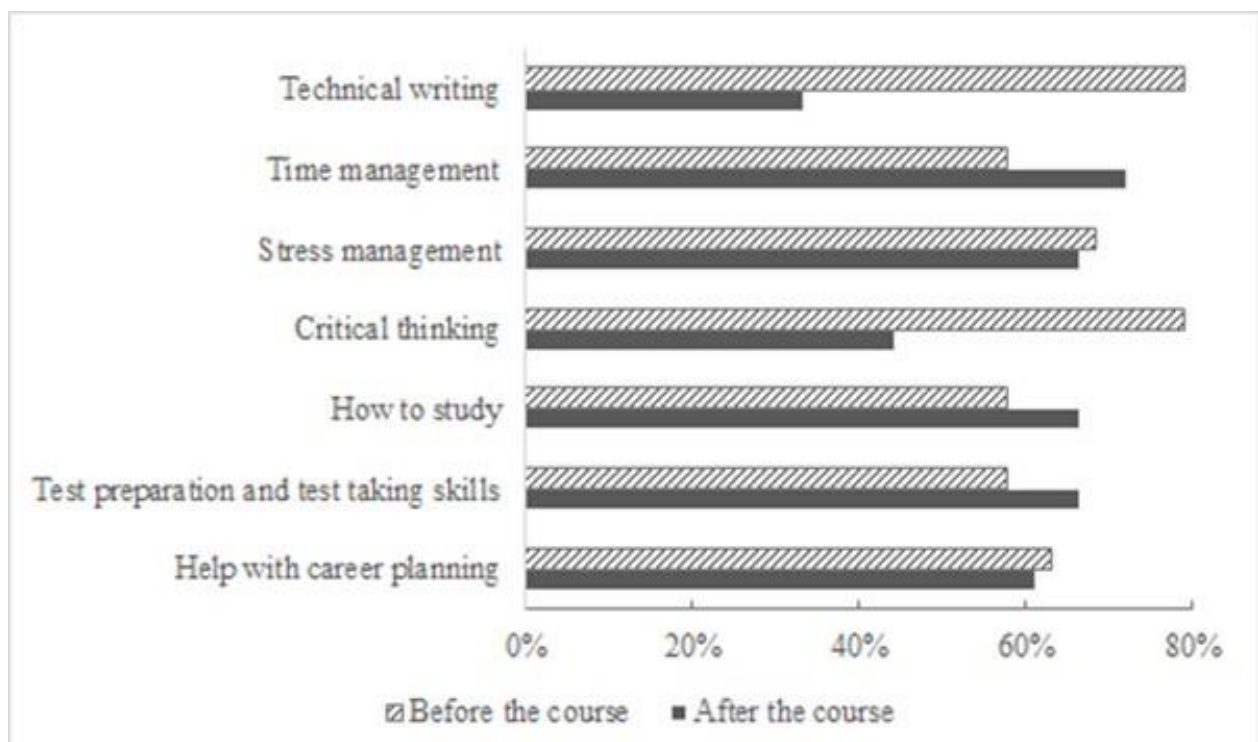

Figure 2: Percent of students that said they would appreciate instruction or guidance in each of the noted areas, before and after the course. Data shown for the 2018 cohort of students only.

Areas where students were less interested in additional instruction were "Technical Writing" and "Critical Thinking." We hypothesize that student's felt more confident in their critical thinking skills, because a majority of the questions in the course were open-ended and/or long-form or project-based problems. However, a majority of the scientific communication required in the course was short laboratory reports and presentations with a majority of associated teaching time was spent on assessing tables, plots, and scientific content rather than writing. Future iterations of the course will include further instruction and explicit feedback on writing.

\section{STEM engagement study}

In addition to assessing their competence in course material, students completed a questionnaire at the end of the course designed to measure whether their attitudes towards STEM had changed. Specifically, we were interested in whether students were more interested in STEM related topics, and whether their career choices were impacted by taking the course. The results for the questions on engagement for the 2018 cohort are shown in Figure 3. The 2017 cohort reported responses on a 4-point scale, and 2018 students reported on a 10-point scale, however, results from the 2017 cohort (not shown) mirrored the trends shown in Figure 3. 


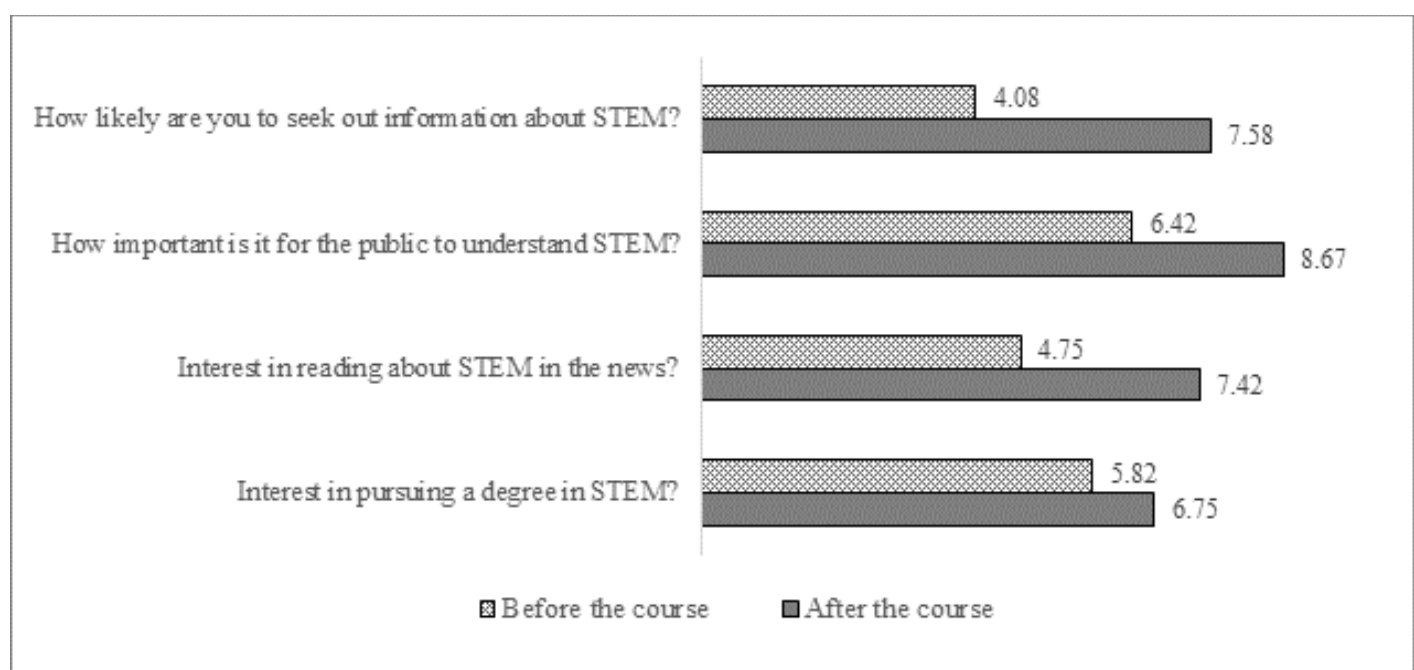

Figure 3: Results from student surveys on STEM engagement reported on a 10-point scale (Averages shown are for 2018 cohort only).

The most significant gains measured in the engagement survey were in "How likely are you to seek out information about STEM." The lowest gains were in "Interest in pursuing a degree in STEM." This may be because students, particularly those driven to seek out a college-credit bearing summer course in their junior or senior year of high school, already have formed their interests and ideas about their career. The 2017 cohort was also asked whether they were interested in pursuing a graduate level degree in STEM and, for this question, significant gains were measured. Thus, even if it didn't change the students intended field of study, it may have affected longer term ideas of what their career might look like. The results of the engagement study show that after the course students had a better appreciation for the importance of STEM in the world, but that this appreciation didn't significantly impact their career plans, which were likely already formed.

In addition to the questions shown in Figure 3, students also were asked which aspects of the course contributed to their increased interest in STEM. This question was only asked for the 2018 cohort of students. The results are shown in Table 3. All surveyed students in the 2018 cohort said that feeling more confident in their abilities in science, math and engineering increased their interest in STEM. Also, students said that learning about the applications of science, math and engineering in class increased their interest in STEM more than the field trip to the steam plant or laboratory work. We hypothesize that this is because the teaching of applications of chemistry, engineering and math, specifically its relevance to topics like climate change and energy, was more novel in their education than laboratory work or field trips. 
Table 3: Responses to "Which of the following aspects of the course impacted your interest in science/engineering?" Average responses for 2018 cohort only.

\begin{tabular}{|l|l|l|l|}
\hline & $\begin{array}{l}\text { Decreased } \\
\text { Interest }\end{array}$ & No impact & $\begin{array}{l}\text { Increased } \\
\text { Interest }\end{array}$ \\
\hline $\begin{array}{l}\text { Feeling better about my abilities in science, math } \\
\text { and engineering }\end{array}$ & $0 \%$ & $0 \%$ & $100 \%$ \\
\hline $\begin{array}{l}\text { Learning about real-world applications of science, } \\
\text { math or engineering }\end{array}$ & $0 \%$ & $8 \%$ & $92 \%$ \\
\hline Getting exposure to laboratory work & $0 \%$ & $15 \%$ & $85 \%$ \\
\hline Field trip to the Steam Plant & $0 \%$ & $46 \%$ & $54 \%$ \\
\hline Learning more about career options in STEM & $0 \%$ & $15 \%$ & $85 \%$ \\
\hline
\end{tabular}

After the questions on STEM engagement, the 2017 and 2018 cohort were asked for feedback on how to improve the course. Students were asked to reflect on: 1) What things they would recommend changing in future years 2) What things they would keep the same 3) How the course was different from a traditional high school class and to 4) Reflect on the 1-3 most important technical things they learned and to 5) Reflect on the 1-3 most important non-technical things they learned. All of these questions were free response. A majority of students in both cohorts noted aspects of the applications section of the course (i.e. "Learning where electricity comes from") as the most important technical skills they learned. A majority of both cohorts said that the course was different from their high school classes because they had more independence (several students reported "having more freedom" than in a high school class). The two cohorts differed in their responses for what the students learned non-technically. The most common responses for the 2018 cohort was time management and for the 2017 cohort the most common responses included "office hours" or "networking." These differences were likely because the 2017 cohort had several guest lectures (with whom to network) and the 2018 cohort were given more independent time to manage. A majority of students in both cohorts did not have recommendations for changes to the course. This may be because this was the first experience for the students taking a college course; they had no reference to compare to.

One aspect of the course that students did not give feedback on that were explicitly built into the curriculum were techniques of differentiation, specifically, peer tutoring, office hours, and additional resources. Future assessment may ask for feedback on these techniques. Future assessment may also ask students to reflect on the interdisciplinary design of the course and the design of teaching and using specific skills in different sections simultaneously.

\section{Retention in College Now Programs}

College preparation of high school students was one aspect of the summer bridge program. While during the study, many of the cohort have not graduated high school yet, a marker for continued interest and investment by the students in attending college are their participation in other College Now courses offered during the academic year. For the 2017 cohort (2018 cohort is still enrolling in courses for spring, so the data is incomplete), $73 \%$ of the students participated 
in continuing College Now semesters, covering different courses, 53\% of the 2017 cohort enrolled in one additional College Now semester course (Fall 2017 or Spring 2018) and 20\% of the 2017 cohort enrolled in two additional College Now semesters (both Fall 2017 and Spring 2018). One third of the 2017 cohort, or $45 \%$ of the students who continued to participate in the College Now program, took a College Now version of ENG 11: Introduction to Engineering. This illustrates their continued interest in STEM following the summer bridge program.

\section{Conclusions}

This paper evaluates a college program that covers material from chemistry, math, engineering, and non-technical skills. Students improved significantly in using Excel, which they had little experience with prior to the course. This may be because it was used throughout instruction in laboratory and even in mathematics. Students felt more confident about their engineering and math skills after the course and noted that this made them more interested in pursuing a degree in math or science. Students' reflections on the course show the giant step that students make in moving from high school to college and demonstrate the importance of summer courses for high school upperclassman that can fill this gap and prepare students for college both technically and non-technically.

\section{Acknowledgments}

The College Now EST 11 program taught in 2017 and 2018 was jointly supported by the College Now City University of New York program and NSF ATE Project \#1601636 - Chemical and BioEnergy Technology for Sustainability (CBETS). Thank you to Ms. Susana Rivera for providing the demographic information for the program and for her support of the College Now program at BCC.

\section{References}

[1] J. C. Chang, "Women and minorities in the science, mathematics and engineering pipeline," ERIC Digest, p. ED467855, 2002.

[2] J. Jones, A. Williams, S. Whitaker, S. Yingling, K. Inkelas, and J. Gates, "Call to action: Data, diversity, and STEM education," Change: The Magazine of Higher Learning, vol. 50, no. 2, pp. 40-47, 2018/03/04 2018.

[3] "Federal science, technology, engineering, and mathematics (STEM) education 5-year strategic plan. A report from the Committee on STEM Education National Science and Technology Council.," National Science and Technology Council 2013, Available: https://obamawhitehouse.archives.gov/sites/default/files/microsites/ostp/stem_stratplan_2 013.pdf.

[4] "A national science action plan for addressing the critical needs of the U.S. science, technology, and mathematics education system," National Science Board 2017, Available: https://www.nsf.gov/nsb/documents/2007/stem_action.pdf.

[5] A. Sahin, A. Ekmekci, and H. C. Waxman, "The relationships among high school STEM learning experiences, expectations, and mathematics and science efficacy and the likelihood of majoring in STEM in college," International Journal of Science Education, vol. 39, no. 11, pp. 1549-1572, 2017/07/24 2017. 
[6] R. Lamb et al., "Psychosocial factors impacting STEM career selection," The Journal of Educational Research, vol. 111, no. 4, pp. 446-458, 2018/07/04 2018.

[7] M. W. Moakler Jr. and M. M. Kim, "College major choice in STEM: Revisiting confidence and demographic factors," The Career Development Quarterly, vol. 62, no. 2, pp. 128-142, 2014.

[8] G. S. May and D. E. Chubin, "A retrospective on undergraduate engineering success for underrepresented minority students," Journal of Engineering Education, vol. 92, no. 1, pp. 27-39, 2003.

[9] M. G. Eastman, J. Christman, G. H. Zion, and R. Yerrick, "To educate engineers or to engineer educators?: Exploring access to engineering careers," Journal of Research in Science Teaching, vol. 54, no. 7, pp. 884-913, 2017.

[10] S. G. Brainard and L. Carlin, "A six-year longitudinal study of undergraduate women in engineering and science," Journal of Engineering Education, vol. 87, no. 4, pp. 369-375, 1998.

[11] E. Litzler, C. C. Samuelson, and J. A. Lorah, "Breaking it down: Engineering student STEM confidence at the intersection of race/ethnicity and gender," Research in Higher Education, journal article vol. 55, no. 8, pp. 810-832, December 012014.

[12] M. Besterfield-Sacre, C. J. Atman, and L. J. Shuman, "Characteristics of freshman engineering students: Models for determining student attrition in engineering," Journal of Engineering Education, vol. 86, no. 2, pp. 139-149, 1997.

[13] T. Huziak-Clark, T. Sondergeld, M. van Staaden, C. Knaggs, and A. Bullerjahn, "Assessing the impact of a research-based STEM program on STEM majors' attitudes and beliefs," School Science and Mathematics, vol. 115, no. 5, pp. 226-236, 2015.

[14] C. Cairncross, S. A. Jones, Z. Naegele, and T. VanDeGrift, "Building a summer bridge program to increase retention and academic success for first-year engineering students," 122nd ASEE Annual Conference \& Exposition, 2015, pp. 26.300.01-26.300.24: American Society for Engineering Education.

[15] J. Cruz and N. Kellam, "Beginning an engineer's journey: A narrative examination of wow, when, and why students choose the engineering major," Journal of Engineering Education, vol. 107, no. 4, pp. 556-582, 2018.

[16] J. L. DeGrazia, J. F. Sullivan, L. E. Carlson, and D. W. Carlson, "A K-12/University partnership: Creating tomorrow's engineers," Journal of Engineering Education, vol. 90, no. 4, pp. 557-563, 2001.

[17] P. Cantrell and J. Ewing-Taylor, "Exploring STEM career options through collaborative high school seminars," Journal of Engineering Education, vol. 98, no. 3, pp. 295-303, 2009.

[18] H. M. Doerr, J. B. Ärlebäck, and A. Costello Staniec, "Design and effectiveness of modeling-based mathematics in a summer bridge program," Journal of Engineering Education, vol. 103, no. 1, pp. 92-114, 2014.

[19] R. Kowalchuk, T. Green, R. Ricks, and J. Nicklow, "Evaluation of a summer bridge program on engineering students' persistence and success," in 117th ASEE Annual Conference \& Exposition, Louisville, KY, 2010, pp. 15.536.1-15.536.16: American Society for Engineering Education.

[20] M. W. Ohland and G. Zhang, "A Study of the impact of minority engineering programs at the FAMU-FSU College of Engineering," Journal of Engineering Education, vol. 91, no. 4, pp. 435-440, 2002. 
[21] W. C. Lee and H. M. Matusovich, "A model of co-curricular support for undergraduate engineering students," Journal of Engineering Education, vol. 105, no. 3, pp. 406-430, 2016.

[22] C. Papadopoulos and J. Reisel, "Do students in summer bridge programs sucessfully improve math placement and persist? A meta analysis," in 2018 Annual Conference \& Exposition American Society of Engineering Education, Pittsburgh, PA, 2008, pp. AC 2008-1623.

[23] (2018, February 4, 2019). College Now. Available: http://www2.cuny.edu/about/administration/offices/evaluation/areas-offocus_1/college_readiness/college-now/

[24] "Data Snapshot: College Now Participation Report Academic Year 2016-2017," City University of New York, New York2018, Available: http://www2.cuny.edu/wpcontent/uploads/sites/4/media-assets/Finalized-Participation-Snapshot-FY2016-1720180807.pdf

[25] M. B. Kubilius, R. S. Tu, and R. Anderson, "Integrating the ChE curriculum via a recurring laboratory," Chemical Engineering Education, vol. 48, no. 4, pp. 221-230, 2014. 